\title{
Editorial
}

\author{
Chen Zhi \\ Editor-in-Chief; Research Centre for History and Culture, Beijing Normal \\ University \& UIC, Beijing, China
}

\section{Carlotta Viti}

Associate Editor; Research Centre for History and Culture, Beijing Normal University \& UIC, Beijing, China

\author{
Shawn Wang \\ Associate Editor; Research Centre for History and Culture, Beijing Normal \\ University \& UIC, Beijing, China
}

This new peer-reviewed journal, published since 2021, is devoted to the scholarly study of the ancient civilizations of the Old World, that is, Africa, Europe, and Asia, from a historical, social, cultural, and linguistic perspective. Its publication is supported by the Research Centre for History and Culture of Beijing Normal University (Zhuhai Campus) and of UIC, ${ }^{1}$ in China, the homeland of one of the oldest world's civilizations. The journal was founded by Professor Chen Zhi (as Editor-in-Chief), Professor Carlotta Viti and Dr. Shawn Wang (as Associate Editors) in 2020. In addition to our team at Beijing Normal University, the journal hosts an international editorial and advisory board represented by well-known scholars from different universities and with different research interests within the field of antiquity. It is published in Open Access, in order to allow everybody, even readers from disadvantaged milieus, to read and download articles for free, in a truly inclusive spirit, as we will see below.

Although various publications exist on different ancient cultures, our journal is quite distinctive in its methods and aims, as well as in its very concept of

1 While Beijing Normal University is one of the most important universities of China and of Asia, UIC (=Beijing Normal University - Hong Kong Baptist University United International College) represents the first full-scale cooperation in higher education between the Chinese Mainland and Hong Kong. It is situated in Zhuhai city in the Guangdong-Hong Kong-Macao Greater Bay Area of the Pearl River. 
antiquity. Traditionally, antiquity is set between prehistory and the fall of the Western Roman Empire in the 5 th century CE. We find, however, this terminus ante quem to be too Eurocentric and restrictive, since the main developments of several important Asian and African civilizations would be unduly omitted. The golden age of the Muslim world, for example, corresponds to what is considered to be the "dark age" or the "Middle Ages" in Europe. We aim therefore at offering a more comprehensive perspective on world civilizations developed in pre-modern times, by proposing a broader chronological span from prehistory to the fall of the Eastern Roman Empire, in the 15th century CE.

These broad coordinates in space and in time are designed so as to accompany the study of antiquity with a comparative and interdisciplinary perspective, ranging from history, archeology, art and architecture to philology, literature, philosophy, religious studies, sociology, anthropology, linguistics, etc. Comparison and interdisciplinarity are not a necessary requirement of an individual paper, as they may result from the collection of the various papers included in an issue. The topic of an article is therefore completely free, the only requirement being the study of an aspect of antiquity in Africa and Eurasia. ${ }^{2}$ Within this broad scope of topics, some leitmotifs will be identified that examine a certain area or a certain era, so that the reader may be well oriented through his/her favorite research interests and at the same time obtain unique insights from different aspects of antiquity. In the future, we plan to additionally publish special issues, characterized by a more focused and in-depth subject of study, in addition to the regular general issues - the next one, to be published in 2022-2023, will be devoted to the theme of the Bronze Age.

This broad thematic coverage also stems from a non-Eurocentric perspective and is in keeping with Asian modes of holistic knowledge production. Although different Asian cultures may have different traditions, of course, they still may present some common cultural patterns. Whoever is familiar with the ancient texts of various Asian civilizations, from the Middle East to South Asia, Southeast Asia, Central Asia and Eastern Asia, is aware that their expressions of knowledge are essentially inclusive and multidisciplinary, and that their author was often at the same time a poet, a philosopher, a spiritual leader, a natural scientist, able to give directions on the ways of governing a city as well as to solve mathematical problems. ${ }^{3}$ Even nowadays, when most Asian countries purport

2 For details about the content and form of paper submissions, please visit the website of our journal at https://brill.com/view/journals/ow/ow-overview.xml?language=en.

3 Actually, this holistic perspective can also be found in the West in ancient times, for example in the word of pre-Socratic thinkers (who have been often considered, following Aristotle, as the 
a secular education, this ancient holistic framework remained. The motto of the university which co-hosts this journal, UIC, for example, is "in knowledge and in deeds, unto the whole person", which concisely represents a typical Asian approach of combining theoretical knowledge and practical experience. Of course, this does not imply a superficial knowledge: it rather implies to deeply cultivate one discipline and at the same time to have some basic information about other fields which are related to that discipline. Even though one cannot be a specialist of many different disciplines, having some understanding of them will help him/her to better comprehend his/her own subject.

This holistic and interdisciplinary knowledge may have numerous expressions in language, literature, and culture in general. On the one hand, from a linguistic point of view, it is common in Asia that people - even non-scholarly people - are able to speak fluently in different languages. On the other, from the point of view of literature, it is also common in Asia that texts present the structure of a story inside a story - an example can be seen in the multiple narrative frames of the Mahābhārata, where the story told by the sage Vaiśampāyana to the king Janamejaya at the great snake sacrifice is just the first of a series of embedded frames and stories on a myriad of different topics (stories of love, friendship, betrayal, addiction to gambling, religious speeches, philosophical reflections, birth and death), besides the narrative core of the great battle between the Kauravas and the Pāndavas, to the point that it is said that "what is here can also be found elsewhere, but what is not here is found nowhere else". Even apart from special cases such as the Mahābhārata or the Rāmāyana, Indian literature is replete with examples of a story inside another story - it is a different way of narrating, which may disorient the reader not accustomed to it. In fact, when European scholars first approached the Mahābhārata and the Indian narrative structure, they did not appreciate it and considered it clumsy, chaotic, and even devoid of any poetic sense. Of course, nothing is less true. Still, this lack of appreciation let many masterpieces of Asian literature be ignored for centuries, and even now few Western non-academic readers

first example of rational thinking, while nowadays they are better understood in the light of a more ancient 'shamanic' wisdom, originally developed in Mesopotamia, combining poetry, reflection on nature, divination, and healing skills). In later stages of Greco-Roman culture, however, which has so deeply influenced Western intellectual history, this ancient wisdom has profoundly changed into a kind of logical thinking attentive to specialization and capable of generating new original ideas in a precise disciplinary field; notions of originality, authorship

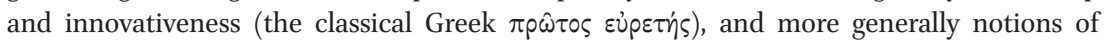
progress, are central to the classical world and later to the Western cultural history at least since the Renaissance. In Asia, instead, the power of tradition has been always stronger, to the point that texts or pieces of art and architecture continue to imitate or to be freely inspired by their ancient models. 
may be found that know the treasures of the Shāh-nāmeh of Ferdowsī, of the Rubā'iyāt of Omar Khayyām, of the Gulistān of Sa'dī, of the Mathnavī of Rūmī, of the Divān of Hâfez, just to mention a few classics from Persian literature. On the other hand, few Asian readers, apart from academics, comprehend classics of ancient Western civilizations such as the Iliad and the Odyssey, Herodotus, Plato, and so on, so that these two worlds, East and West, both characterized by ancient and illustrious cultural traditions, often do not know each other. The study of Ancient Africa is also neglected. Still, Africa is not only the homeland of Ancient Egypt, one of the world's most ancient civilizations, but is also the cradle of a long uninterrupted tradition of oral narratives, as well as of an amazingly diverse linguistic, cultural, and geopolitical landscape. We are proud to devote our journal's first paper precisely to Ancient Africa.

This short editorial cannot explore the many historical, social, and cultural factors underlying the differences and similarities between the modern Western epistemic approach (based on a clearer separation between theoretical and practical knowledge, as well as on a separation among delimited disciplinary fields, where interdisciplinarity may well be cultivated but is sporadic or implies the involvement of different people) and the Eastern epistemic approach (holistic, cross-disciplinary in essence, and based on the simultaneous cultivation of different topics, different styles, or different languages), the latter being also typical of the West in pre-modern times. No approach is inherently superior. Both may have strong and weak points, and they may be more or less well-suited in different contexts. Their comparison must not be meant in an evaluative sense. We rather stress this cultural comparison as a bridge to know something else, which may help to better understand one's own subject of study. This is the aim of our journal: to proffer to the West some concepts and products of Asian cultural legacy, to receive some fruits of Western history of ideas, to increase the understanding of Ancient Africa, to favor reciprocal knowledge and cross-cultural respect, and ultimately to contribute to the scientific dialogue between East and West - a dialogue and intellectual journey started thousands of years ago. 